\title{
Analisis Pengaruh Ukuran Stopper Pada Sambungan Pelat Kapal Terhadap Tegangan Sisa Dan Deformasi Menggunakan Metode Elemen Hingga
}

\author{
Rafid Buana Putra, Achmad Zubaydi, Septia Hardy Sujiatanti \\ Departemen Teknik Perkapalan, Fakultas Teknologi Kelautan, Institut Teknologi Sepuluh Nopember \\ (ITS) \\ e-mail: zubaydi@na.its.ac.id, septi@na.its.ac.id
}

\begin{abstract}
Abstrak-Dalam proses pengelasan dapat terjadi deformasi dan meningkatnya tegangan sisa pada material. Maka dari itu dipasanglah stopper dalam proses positioning. Dalam proses pengelasan, stopper digunakan untuk membantu welder untuk mengekang pelat yang akan dilas. Dengan menggunakan stopper, pelat yang dilas tidak akan bergeser dan deformasi pada pelat dapat diminimalkan. Adapun tujuan dari penelitian ini adalah untuk mengetahui ukuran optimum dari stopper yang digunakan dalam proses pengelasan. Ukuran optimum dapat diketahui dari besarnya deformasi dan tegangan sisa yang terjadi pada pelat logam induk dengan variasi ukuran stopper (panjang 200, 300, 400, 500, dan $600 \mathrm{~mm}$ ) dan variasi bentuk alur las (persegi, $v$ tunggal, dan $v$ ganda). Analisis dilakukan menggunakan metode elemen hingga dengan membuat pemodelan pengelasan pelat baja yang dipasangi stopper. Dari hasil pemodelan dan analisis, didapatkan hasil yaitu deformasi dan tegangan sisa maksimum terjadi pada panjang stopper $200 \mathrm{~mm}$ yaitu $2.40 \mathrm{~mm}$ dan $184.82 \mathrm{MPa}$. Sebaliknya, deformasi dan tegangan sisa minimum terjadi pada panjang stopper $600 \mathrm{~mm}$ yaitu $1.88 \mathrm{~mm}$ dan $138.29 \mathrm{MPa}$. Dapat disimpulkan bahwa semakin panjang stopper yang digunakan maka deformasi dan tegangan sisa yang dihasilkan semakin kecil. Dari hasil analisis didapat tegangan sisa pada variasi panjang stopper $200 \mathrm{~mm}$ masih di bawah yield stress, maka stopper paling optimum adalah panjang stopper $200 \mathrm{~mm}$ dan tidak perlu dilakukan analisis untuk panjang stopper lebih dari $600 \mathrm{~mm}$.
\end{abstract}

Kata Kunci-Metode Elemen Hingga, Stopper, Tegangan Sisa, Deformasi.

\section{PENDAHULUAN}

$\mathrm{B}$ ERDASARKAN definisi dari Deutche Industrie Normen (DIN), las adalah ikatan metalurgi pada sambungan logam atau logam paduan yang dilaksanakan dalam keadaan lumer atau cair. Dari definisi tersebut dapat dijabarkan lebih lanjut bahwa las adalah sambungan setempat dari beberapa batang logam dengan menggunakan energi panas [1].

Dari definisi tersebut, dapat disimpulkan bahwa pengelasan merupakan salah satu teknik penyambungan material logam dengan cara mencairkan sebagian logam induk (base metal) dan logam pengisi (filler metal) dengan atau tanpa tekanan dan dengan atau tanpa logam penambah dan menghasilkan sambungan yang kontinu. Dalam proses pengelasan itu sendiri, terdapat beberapa tahap persiapan yang perlu dilakukan berupa persiapan material, prosedur pengelasan, dan positioning.

Dalam praktiknya, proses pengelasan juga dapat menyebabkan deformasi dan meningkatkan tegangan sisa. Deformasi disebabkan karena adanya pengaruh dari besarnya panas yang diberikan (heat input) selama proses pengelasan yang berakibat pada kekuatan material menerima beban kejut (impact). Sedangkan tegangan sisa disebabkan karena adanya penyusutan pada waktu pendinginan setelah pengelasan. Oleh karena itu, dilakukan beberapa cara untuk meminimalkan deformasi dan tegangan sisa. Salah satunya adalah dengan menggunakan stopper pada material yang akan dilas. Namun penggunaan stopper yang berlebihan dapat menimbulkan tegangan sisa pada material, sehingga dapat menyebabkan retak pada hasil pengelasan.

Dalam studi ini akan dianalisis pengaruh ukuran stopper terhadap tegangan sisa dan deformasi pada base metal dengan variasi bentuk alur las untuk mengetahui ukuran ideal dari stopper yang digunakan pada masing-masing bentuk alur las. Proses analisisakan dilakukan menggunakan simulasi metode elemen hingga dengan membandingkan variasi ukuran stopper dan bentuk alur las sehingga didapatkan nilai tegangan sisa dan deformasinya.

\section{STUDI LITERATUR}

\section{A. Pengelasan}

Proses awal pengelasan dimulai dari proses penyambungan logam yang sudah ada sebelum era revolusi industri yaitu dengan cara membuat cetakan berbahan pasir di atas pelat logam dan mengisinya dengan logam cair. Cetakan ini dapat dibentuk sesuai dengan bentuk yang diinginkan. Selain itu, proses penyambungan logam juga dilakukan dengan menyambung dua pelat logam dengan logam cair. Pada akhir abad ke-19, cara-cara dan teknik pengelasan mulai berkembang pesat yaitu dengan menggunakan energi listrik dan berkembang hingga sekarang.

Sambungan las adalah dua atau lebih material yang digabungkan melalui proses pengelasan. Ada 5 tipe dasar dari sambungan las antara lain butt, tee, corner, lap dan edge joint. Pada dasarnya dalam memilih bentuk alur harus menuju kepada penurunan masukan panas dan penurunan logam las sampai kepada harga terendah yang tidak 
menurunkan mutu sambungan las. Karena hal ini maka dalam pemilihan bentuk alur diperlukan kemampuan dan pengalaman yang luas. Bentuk-bentuk yang telah distandarkan pada umumnya hanya meliputi pelaksanaan pengelasan yang sering dilakukan sehingga dalam pengelasan khusus bentuk alur harus ditentukan sendiri berdasarkan pengalaman yang dipercaya [1].

\section{B. Perpindahan Panas}

Hampir semua proses pengelasan dilakukan dengan cara melakukan pemanasan setempat atau lokal. Beban heat input yang diberikan pada saat pengelasan menyebabkan peningkatan temperatur material yang terkena busur api las sampai pada suhu lebur. Perubahan temperatur pada daerah yang mengalami kontak langsung dengan busur las berlangsung dengan sangat cepat sehingga menciptakan perbedaan temperatur dengan daerah di dekatnya. Segera setelah perbedaan temperatur terjadi panas mulai mengalir ke sekitar daerah pengelasan yang mempunyai temperatur lebih rendah sehingga terjadi distribusi panas ke daerah sekitar alur las [2].

Dalam proses pengelasan tidak semua energy digunakan untuk memanaskan elektroda dan logam las. Sebagian energy yang dihasilkan terserap ke lingkungan karena adanya kontak dengan udara lingkungan sekitar, sehingga energi efektif yang digunakan dalam pengelasan dapat dirumuskan pada Persamaan 1:

$$
\mathrm{Q}=\dot{\eta} \mathrm{U} \mathrm{I}
$$

dimana:

$\mathrm{Q}=$ Heat input bersih (Watt)

$\eta \dot{\eta}=$ Koefisien dari efisiensi las

$\mathrm{U}=$ Tegangan yang digunakan pada saat pengelasan (Volt)

I = Kuat arus (Ampere)

Sedangkan besarnya heat flux yang dikenakan pada material ditentukan dengan Persamaan 2 dan Persamaan 3:

$$
\begin{aligned}
& \mathrm{q}_{1}=\mathrm{q}_{\mathrm{e}} \frac{A 1}{A f} \\
& \mathrm{q}_{\mathrm{e}}=\frac{Q}{A \theta}
\end{aligned}
$$

dimana:

$\mathrm{A}_{1}=$ Luas area elemen yang dikenai beban heat input $\left(\mathrm{mm}^{2}\right)$

$\mathrm{A}_{\mathrm{f}}=$ Luas area pembebanan yang dihasilkan dari proses pengelasan $\left(\mathrm{mm}^{2}\right)$

$\mathrm{A}_{\mathrm{e}}=$ Luas area elektroda yang digunakan $\left(\mathrm{mm}^{2}\right)$

Sedangkan untuk mencari $\mathrm{A}_{\mathrm{f}}$, digunakan Persamaan 4:

$$
A_{f}=b \times v \times t
$$

dimana:

$\mathrm{b}=$ Lebar kampuh las ( $\mathrm{mm})$

$\mathrm{v}=$ Kecepatan pengelasan satu elemen $(\mathrm{mm} / \mathrm{s})$

$\mathrm{t}$ = waktu yang diperlukan untuk mengelas satu elemen (s)

\section{Tegangan Sisa}

Tegangan sisa selalu muncul apabila sebuah material dikenai perubahan temperatur non-uniform, tegangantegangan ini disebut tegangan panas. Untuk membahas masalah pengelasan,tegangan sisa yang akan ditinjau adalah tegangan sisa yang ditimbulkan dari distribusi regangan nonelastik yang tidak merata pada material. Tegangan sisa pada logam dapat terjadi karena banyak hal selama proses produksi antara lain:

a. Material yang termasuk bentuk pelat dan batangan dikenal dengan proses roll, casting, dan forging.

b. Selama pembentukan bagian-bagian logam oleh prosesproses seperti bending, grinding, shearing, dan machining.

c. Selama proses fabrikasi, seperti pengelasan.

\section{Deformasi Pengelasan}

Pada dasarnya deformasi dapat terjadi karena panas dan gaya luar. Panas dapat terjadi karena proses pengelasan atau pemotongan dengan las. Pada proses pengelasan, hal-hal yang memengaruhi deformasi adalah yang berhubungan dengan panas pengelasan dan juga yang berhubungan dengan penahan atau penghalang pada sambungan las [3].

\section{E. Stopper}

Stopper merupakan alat penahan yang terbuat dari pelat dengan ketebalan sekitar $10 \mathrm{~mm}$ dipasang dengan sudut $45^{\circ}$ hingga $90^{\circ}$ terhadap garis las. Pelat ini berfungsi sebagai penahan dari kedua pelat yang hendak disambungkan dengan las. Penahanan pada pelat yang akan dilas berguna untuk mencegah terjadinya deformasi pada pelat akibat dari pengelasan. Pemasangan stopper yang berlebihan dapat menyebabkan cacat las di daerah sekitar stopper. Bentuk stopper digambarkan pada Gambar 1[4].

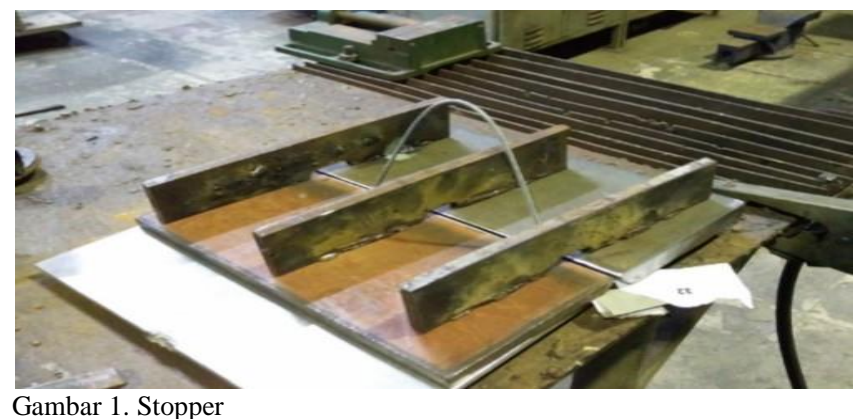

\section{F. Metode Elemen Hingga}

Metode elemen hingga merupakan metode numerik yang digunakan untuk menyelesaikan permasalahan dalam bidang rekayasa seperti geometri, pembebanan dan sifat-sifat dari material yang sangat rumit. Selain itu, metode ini juga dapat digunakan untuk menyelesaikan masalah structural, thermal, dan elektromagnetik. Dalam metode ini, seluruh masalah yang kompleks seperti variasi bentuk, kondisi batas, dan beban diselesaikan dengan metode pendekatan. Pendekatan metode elemen hingga adalah menggunakan informasiinformasi pada titik simpul (node). Dalam proses penentuan titik simpul yang di sebut dengan pendeskritan (discretization), suatu sistem dibagi menjadi bagian-bagian yang lebih kecil, kemudian penyelesaian masalah dilakukan pada bagian-bagian tersebut dan selanjutnya digabung kembali sehingga diperoleh solusi secara menyeluruh [5].

Dalam pengerjaan Studi ini, digunakan software metode elemen hingga. Software ini adalah program paket yang dapat memodelkan elemen hingga untuk menyelesaikan masalah yang berhubungan dengan mekanika, termasuk di dalamnya masalah static, dinamik, analisis structural (baik 
linier maupun nonlinier), masalah perpindahan panas, masalah fluida, dan juga masalah yang berhubungan dengan akustik dan elektromagnetik. Secara umum penyelesaian elemen hingga dapat dibagi menjadi tiga tahap, yaitu:

\section{1) Preprocessing: pendefinisian masalah}

Langkah umum dalam preprocessing terdiri dari mendefinisikan keypoint/lines/areas/volume, mendefinisikan tipe elemen dan bahan yang digunakan/sifat geometrik, dan mesh lines/areas/volumes sebagaimana yang dibutuhkan. Jumlah detail yang dibutuhkan akan tergantung pada dimensi daerah yang dianalisis: 1D, 2D, axisymmetric, dan 3D.

\section{2) Solution: assigning loads, constraints, and solving}

Di bagian ini, perlu menentukan beban (titik atau tekanan), constraints (translasi dan rotasi), dan kemudian menyelesaikan hasil persamaan yang telah diset.

3) Postprocessing: further processing and viewing of the results

Dalam bagian ini, pengguna dapat melihat: daftar pergeseran nodal, gaya elemen dan momentum, plot deflection, dan diagram kontur tegangan (stress) atau pemetaan suhu [6].

\section{METODOLOGI}

Pada tahap ini dilakukan pemodelan thermal dan struktur pelat kapal yang akan digunakan untuk analisis menggunakan metode elemen hingga. Pemodelan dilakukan secara global dengan menggunakan software finite element analysis (FEA software). Hasil dari pemodelan ini adalah untuk mendapatkan nilai deformasi dan tegangan sisa yang diteliti dengan variasi panjang stopper dan alur las.

\section{A. Pembuatan Geometri}

Geometri pada model dilakukan dengan menggunakan sketsa (sketch). Karena model yang dibuat lebih sederhana, maka hal pertama yang dibuat adalah sketsa pelat $1800 \mathrm{x}$ $6000 \mathrm{~mm}$, kemudian dibuat kampuh las, dan selanjutnya adalah stoppernya.

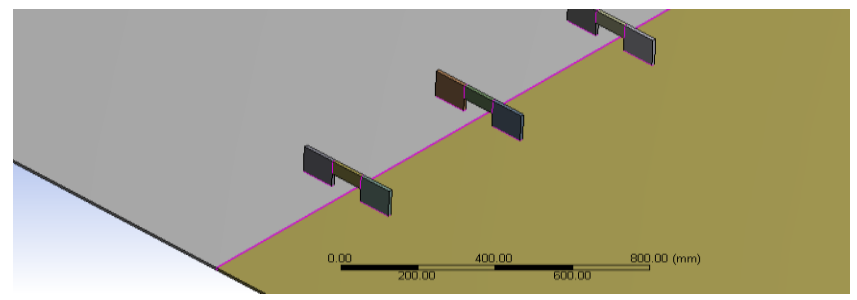

Gambar 2. Pemodelan Geometri

\section{B. Meshing}

Proses selanjutnya adalah proses meshing. Proses ini adalah proses membagi keseluruhan sistem ke dalam elemen-elemen kecil yang seragam dengan tujuan agar analisis menjadi semakin detail pada keseluruhan sistem tersebut.

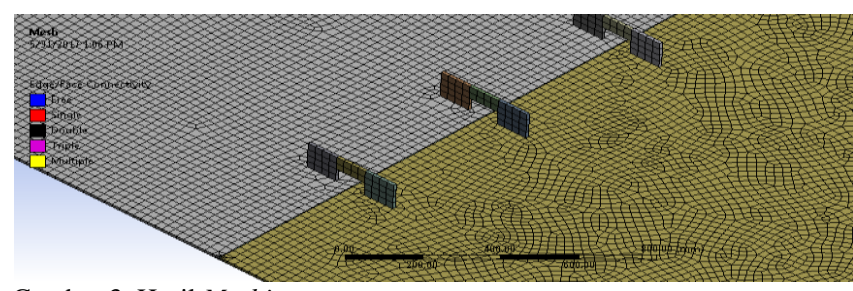

Gambar 3. Hasil Meshing

\section{Pembebanan}

Pembebanan pada analisis thermal adalah memasukkan heat flux dan convection. Proses ini dilakukan sebagai pemodelan pengelasan. Heat flux yang sudah dihitung sebelumnya dimasukkan ke tabular data (time). Begitu pun dengan convection. Hasil dari analisis thermal adalah temperature minimal dan maksimal yang dihasilkan dari heat flux dan convection. Sedangkan untuk analisis struktur, beban yang diberikan adalah hasil analisis thermal. Hasil dari analisis struktur adalah nilai deformasi total dan tegangan sisa.

\section{ANALISIS PERHITUNGAN DAN PEMBAHASAN}

\section{A. Hasil Analisis Thermal}

Setelah dilakukan running analisis thermal pada variasi alur las persegi dan panjang stopper $200 \mathrm{~mm}$, didapatkan hasil seperti pada Gambar 4.

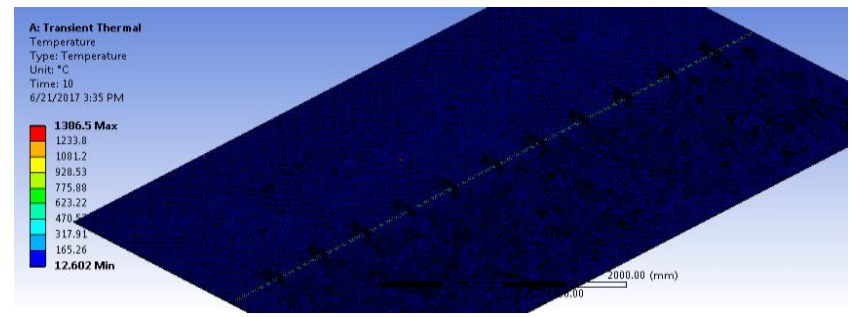

Gambar 4. Hasil Running Analisis Thermal Variasi Alur Las Persegi , Panjang Stopper $200 \mathrm{~mm}$

Pada Tabel 1 adalah rekap dari hasil running analisis thermal pada variasi alur las persegi. Hasil analisis berupa temperatur pada tiap panjang stopper.

Tabel 1.

Hasil Analisis Thermal Variasi Alur Las Persegi

\begin{tabular}{ccc}
\hline \hline No & Jenis Model & Temperatur $(\mathrm{C})$ \\
\hline 1 & Model $200 \mathrm{~mm}$ & 1386.5 \\
2 & Model $300 \mathrm{~mm}$ & 1386.5 \\
3 & Model $400 \mathrm{~mm}$ & 1386.6 \\
4 & Model $500 \mathrm{~mm}$ & 1398.8 \\
5 & Model $600 \mathrm{~mm}$ & 1404.2 \\
\hline \hline
\end{tabular}

Berdasarkan Tabel 1 didapatkan nilai temperatur pada panjang stopper $200 \mathrm{~mm}$ adalah $1386.5{ }^{\circ} \mathrm{C}$, pada panjang stopper $300 \mathrm{~mm}$ adalah $1386{ }^{\circ} \mathrm{C}$, pada panjang stopper 400 $\mathrm{mm}$ adalah $1386.6^{\circ} \mathrm{C}$, pada panjang stopper $500 \mathrm{~mm}$ adalah $1398.8^{\circ} \mathrm{C}$, pada panjang stopper $600 \mathrm{~mm}$ adalah $1404.2{ }^{\circ} \mathrm{C}$. Semakin panjang stopper, maka temperatur hasil uji thermal akan semakin besar. 


\section{B. Hasil Analisis Struktur: Deformasi Total}

Setelah dilakukan running analisis struktur pada variasi alur las persegi dan panjang stopper $300 \mathrm{~mm}$, didapatkan nilai deformasi total seperti pada Gambar 5.

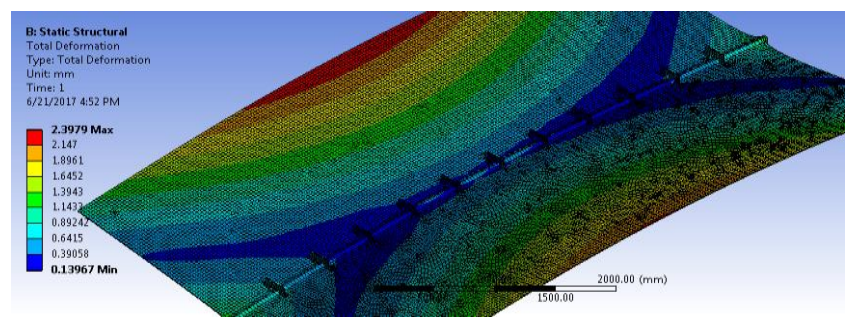

Gambar 5. Hasil Running Deformasi Total Variasi Alur Las Persegi, Panjang Stopper $200 \mathrm{~mm}$

Pada Tabel 2 adalah rekap dari running analisis struktural pada variasi alur las persegi. Hasil analisis berupa besar deformasi total pada tiap panjang stopper.

Tabel 2.

Deformasi Total Variasi Alur Las Persegi

\begin{tabular}{cc}
\hline \hline Panjang Stopper & Deformasi Total $(\mathrm{mm})$ \\
\hline Model $200 \mathrm{~mm}$ & 2.3979 \\
Model $300 \mathrm{~mm}$ & 2.2563 \\
Model $400 \mathrm{~mm}$ & 2.2132 \\
Model $500 \mathrm{~mm}$ & 2.1796 \\
Model $600 \mathrm{~mm}$ & 1.8805 \\
\hline \hline
\end{tabular}

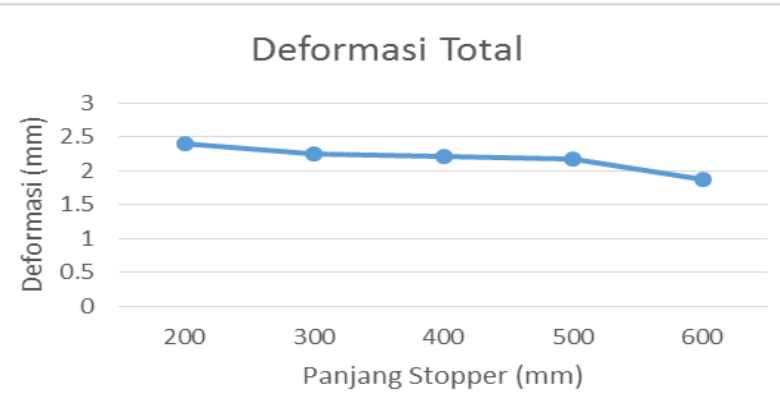

Gambar 6. Grafik Deformasi Total Variasi Alur Las Persegi

Berdasarkan Tabel 2 dan Gambar 6 didapatkan nilai deformasi total pada variasi panjang stopper $200 \mathrm{~mm}$ adalah $2.3979 \mathrm{~mm}$, pada variasi panjang stopper $300 \mathrm{~mm}$ adalah $2.2563 \mathrm{~mm}$, panjang stopper $400 \mathrm{~mm}$ adalah $2.2132 \mathrm{~mm}$, panjang stopper $500 \mathrm{~mm}$ adalah $2.1796 \mathrm{~mm}$, panjang stopper $600 \mathrm{~mm}$ adalah $1.8805 \mathrm{~mm}$. Didapatkan nilai deformasi terkecil pada variasi panjang stopper $600 \mathrm{~mm}$. Dari hasil ini dapat disimpulkan bahwa semakin panjang stopper, maka deformasi yang dihasilkan akan semakin kecil.

\section{Hasil Analisis Struktur: Von Mises Stress}

Setelah dilakukan running analisis struktur pada variasi alur las persegi dan panjang stopper $300 \mathrm{~mm}$, didapatkan nilai tegangan sisa seperti pada Gambar 7.

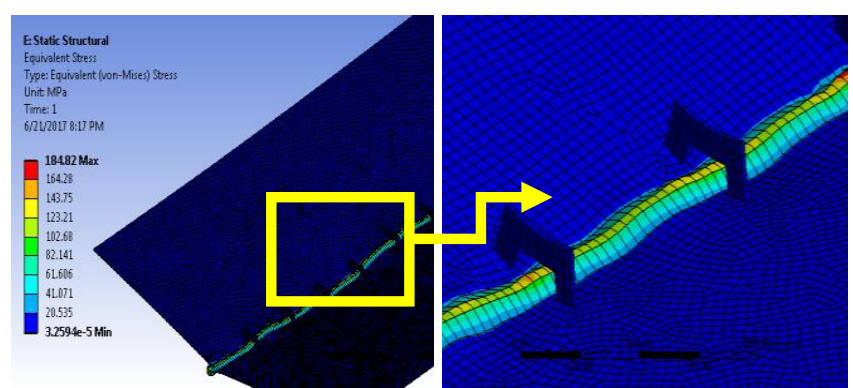

Gambar 7. Hasil Running Analisis Struktur Tegangan Sisa Variasi Alur Las Persegi, Panjang Stopper $200 \mathrm{~mm}$

Pada Tabel 3 adalah rekap dari running analisis struktural pada variasi alur las persegi. Hasil analisis berupa besar tegangan sisa (von mises stress) pada tiap panjang stopper.

Tabel 3.

Tegangan Sisa Variasi Alur Las Persegi

\begin{tabular}{cc}
\hline \hline \multicolumn{2}{c}{ Tegangan Sisa Variasi Alur Las Persegi } \\
\hline Panjang Stopper & Von Mises Stress (MPa) \\
\hline Model $200 \mathrm{~mm}$ & 184.82 \\
Model $300 \mathrm{~mm}$ & 166.32 \\
Model $400 \mathrm{~mm}$ & 156.66 \\
Model $500 \mathrm{~mm}$ & 143.11 \\
Model $600 \mathrm{~mm}$ & 138.29 \\
\hline \hline
\end{tabular}

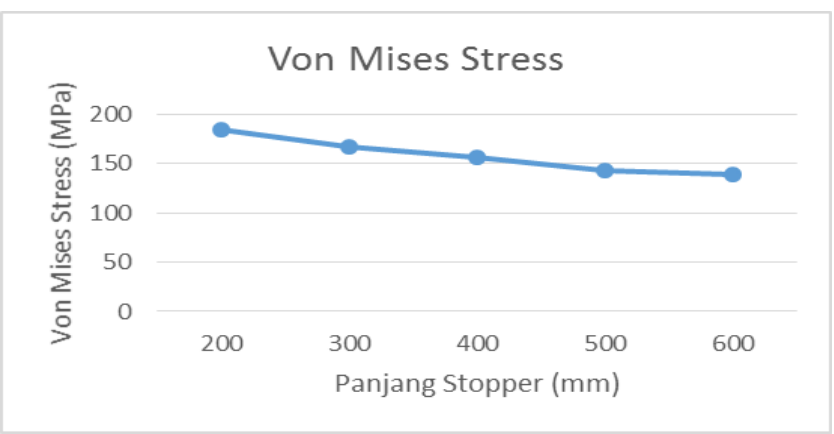

Gambar 8. Grafik Tegangan Sisa Variasi Alur Las Persegi

Berdasarkan Tabel 3 dan Gambar 8 didapatkan nilai tegangan sisa pada variasi panjang stopper $200 \mathrm{~mm}$ adalah 184.82 MPa, panjang stopper $300 \mathrm{~mm}$ adalah $166.32 \mathrm{MPa}$, panjang stopper $400 \mathrm{~mm}$ adalah $156.66 \mathrm{MPa}$, panjang stopper $500 \mathrm{~mm}$ adalah $143.11 \mathrm{MPa}$, dan panjang stopper $600 \mathrm{~mm}$ adalah 138.29 MPa. Didapatkan nilai tegangan sisa terbesar pada variasi panjang stopper $200 \mathrm{~mm}$. Dari hasil ini dapat disimpulkan bahwa semakin panjang stopper, maka nilai tegangan sisa yang dihasilkan akan semakin kecil. Dari hasil running didapat tegangan sisa pada variasi panjang stopper $200 \mathrm{~mm}$ masih di bawah yield stress, maka stopper paling optimal adalah panjang stopper $200 \mathrm{~mm}$ dan tidak perlu dilakukan analisis untuk panjang stopper lebih dari 600 $\mathrm{mm}$.

\section{KESIMPULAN DAN SARAN}

\section{A. Kesimpulan}

1. Deformasi maksimum pada alur las persegi sebesar 2.40 mm terjadi pada variasi panjang stopper $200 \mathrm{~mm}$, sedangkan deformasi minimum sebesar $1.88 \mathrm{~mm}$ pada variasi panjang stopper $600 \mathrm{~mm}$.

2. Deformasi maksimum pada alur las $\mathrm{V}$ tunggal sebesar $2.51 \mathrm{~mm}$ terjadi pada variasi panjang stopper $200 \mathrm{~mm}$, 
sedangkan deformasi minimum sebesar $1.76 \mathrm{~mm}$ pada variasi panjang stopper $600 \mathrm{~mm}$.

3. Deformasi maksimum pada alur las $\mathrm{V}$ ganda sebesar 2.39 $\mathrm{mm}$ terjadi pada variasi panjang stopper $200 \mathrm{~mm}$, sedangkan deformasi minimum sebesar $1.87 \mathrm{~mm}$ pada variasi panjang stopper $600 \mathrm{~mm}$.

4. Tegangan maksimum pada alur las persegi sebesar 184.82 MPa dan tegangan minimum sebesar 138.29 MPa.

5. Tegangan maksimum pada alur las $\mathrm{V}$ tunggal sebesar $169.94 \mathrm{MPa}$ dan tegangan minimum sebesar 132.88 $\mathrm{MPa}$.

6. Tegangan maksimum pada alur las persegi sebesar 183.35 MPa dan tegangan minimum sebesar 132.59 MPa.

7. Semakin besar ukuran stopper maka semakin kecil deformasi dan tegangan sisa yang dihasilkan, tetapi melihat kondisi di lapangan yaitu semakin kecil stopper yang digunakan semakin baik. Maka dapat disimpulkan stopper paling optimal adalah stopper dengan panjang $200 \mathrm{~mm}$.

\section{B. Saran}

1. Jenis karakteristik material yang digunakan adalah ASTM A36. Dapat dilakukan pemodelan dengan jenis material lain sehingga dapat dibandingkan hasil analisanya.

2. Perlu dilakukan analisa dengan variasi panjang stopper yang lebih beragam agar ditemukan hasil yang lebih optimal.

\section{DAFTAR PUSTAKA}

[1] H. dan O. Wiryosumarto, Teknologi Pengelasan Logam. Jakarta: Pradnya Paramita, 2000.

[2] Wahyudi, "Studi Pengaruh Sudut Tanggem Terhadap Retak Pada Pengelasan Butt-Joint dengan Las SMAW," Institut Teknologi Sepuluh Nopember, 1999.

[3] M. Z. Morna, "Analisa Terbentuknya Tegangan Sisa Dan Deformasi Pada Pengelasan Pipa Beda Jenis Menggunakan Metode Elemen Hingga," Institut Teknologi Sepuluh Nopember, 2012.

[4] P. R. Pratama, "Pengaruh Stopper Terhadap Tegangan Sisa dan Deformasi Pada Sambungan Butt Weld Pelat Datar Menggunakan Metode Elemen Hingga," Institut Teknologi Sepuluh Nopember, 2016.

[5] D. L. Logan, A First Course in The Finite Element Method. Platteville: University of Wisconsin, 2005.

[6] K. N. Hoque, "Analysis of Structural Discontinuities in Ship Hull Using Finite Element Method,” 2013. 